\title{
INTERDISCIPLINARY RE-IMAGINING OF THE CONCEPT OF REVELATION
}

\section{Author:}

Daniël P. Veldsman ${ }^{1}$

\section{Affiliation: \\ ${ }^{1}$ Department of Dogmatics and Christian Ethics, University of Pretoria, South Africa}

\section{Correspondence to: Daniël P. Veldsman}

e-mail:

danie.veldsman@up.ac.za

\section{Postal address:}

Department of Dogmatics and Christian Ethics, Faculty of Theology, University of Pretoria Hatfield, 0083, South Africa

\section{Keywords}

revelation;

postfoundationalism evolutionary epistemology; transversal reasoning; religious experience

\section{Dates:}

Received: 03 June 2008 Accepted: 21 Jan. 2009 Published: 24 Apr. 2009

How to cite this article: Veldsman, D.P., 2009, 'Interdisciplinary reimagining of the concept of revelation', HTS Teologiese Studies/Theological Studies 65(1), Art. \#134, 6 pages. DOI: $10.4102 /$ hts.v65i1.134

\section{This article is available} http://www.hts.org.za (c) 2009. The Authors. Licensee: OpenJournals Publishing. This work is licensed under the Creative Commons Attribution License.

\section{ABSTRACT}

For the postfoundationalist Wentzel van Huyssteen, the James I McCord Professor of Theology and Science at Princeton Theological Seminary, USA, the problem of rationality has been the dominant and persuasive theme of his scholarship for more than three decades. 'To understand understanding' can be the shorthand description of his scholarly quest. In his published Gifford Lectures, Alone in the World? (2006), he explores from an interdisciplinary perspective the concept of human uniqueness and the imago Dei-an exercise in transversal reasoning as he calls it. It is an exercise that according to Van Huyssteen, stems from the conviction that evolutionary epistemology creates a natural space for postfoundationalism, and that transversal reasoning represents the performative praxis of postfoundationalism. The question immediately arises from this exciting and promising interdisciplinary exercise, if and how the concept of revelation which represents (in most religions) a constitutive element of religious experience can be understood from a postfoundational perspective as an exercise in transversal reasoning. Against the background of a limited overview of contemporary influential models of revelation, as well as brief notes on natural theology, I will make use of Ricoeur's a-religious understanding of revelation as theological interlocutor for this critical dialogue with Van Huyssteen. Finally I will formulate a tentative framework within which the concept of 'revelation' can be re-imagined from an interdisciplinary perspective so that it can be part of the post-modern theology-science conversation in such a manner to maintain its identity without retreating to an esoteric world of private, insular knowledge claims.

\section{INTRODUCTION}

In his short article on 'Revelation' in the Encyclopedia of Science and Religion, Christopher Knight comes to the following conclusion:

It is perhaps in the context of postfoundationalist understandings of rationality that the concept of revelation will most markedly affect the dialogue of science and theology in the near future. J. Wentzel van Huyssteen's approach, for example, is one that assumes, in the view of some, too great a distinction between theological and scientific rationality. Nevertheless, his way of acknowledging crucial areas of overlap provides a challenge to the simplistic distinction between empirical problems and God's revelation, which is often still held to separate science and theology. This acknowledgement is likely to be of considerable influence in an era profoundly influenced by postmodernist perspectives. A more subtle understanding of revelation than is yet common can, arguably, allow the implications of his insights to be fully explored.

(Knight 2003:737)

Can such a subtle understanding of revelation be re-imagined from the postfoundationalist approach of Van Huyssteen? This question will be addressed from the following two presuppositions which I hold, namely: We need to be told what God is like [In the words of Eberhard Jüngel (1967:27): 'Wenn wir nach dem Sein Gottes fragen, werden wir uns also deshalb von der in der Offenbarung laut werdenden Antwort leiten zu lassen haben...'] and '...(O)ur mental capacities are constrained by their own history ... (and) biological theory of evolution does not tell us everything about the way we know our world' (Van Huyssteen 2006:233; cf. 2007:4). To move beyond the incredible position that humanity can know God without God being willing to be known, is to take as vantage point the Christian notion that God chooses to be known, and consequently, that humanity needs to be told what God is like. If this fundamental Christian notion is traditionally labelled 'revelation', how can it be understood neither as an unacceptable pretension nor as a violent appeal, but as a welcoming address, and then, with rational truthfulness? But even more: How can it be re-modelled from an evolutionary perspective? My shorthand question is thus: How can the 'told' (of revelation) be understood in a broadened evolutionary context from a post-foundational perspective? To explore this 'told', I will initially give a limited overview of contemporary models of revelation on the western theological marketplace with special reference to the French philosopher-theologian Paul Ricoeur. Secondly I will look at the exciting recent contribution of Wentzel van Huyssteen that stems from his postfoundationalist approach, and ultimately, against this background, propose a tentative framework within which the concept of revelation can be re-imagined from a postfoundationalist perspective.

\section{CONTEMPORARY MODELS OF REVELATION}

\section{Introduction}

The contemporary western theological marketplace holds a number of influential models of revelation (cf. Avery Dulles 1983; Alister McGrath 2001:200ff). To name but five:

- Revelation as information (or doctrine). This model is characteristic of conservative evangelical and Catholic neo-scholastic schools in which Scripture and tradition - also the teaching office of the church - form the basis of their respective understandings of revelation in propositional forms.

- Revelation as self-presentation. This model is characteristic of the German dialectical school of theology influenced by the dialogical personalism of Buber in which revelation is understood as a personal communication of God.

- Revelation as experience. This model is characteristic of German liberal Protestantism which centres around human experience, and in which God is understood to be revealed through the experience of the individual. 
- $\quad$ Revelation as poetic discourse. This model is characteristic of the philosophical-theological model of Paul Ricoeur in which he works from an a-religious sense of revelation to an understanding of biblical revelation as poetics and testimony in order to address the pretension of consciousness to constitute itself.

- Revelation as history. This model is characteristic of the distinct approach of the German theologian Wolfhart Pannenberg in which history - and specifically universal and accessible history - is to be understood as revelation.

Since I find the model of Ricoeur especially insightful and fruitful for this proposed exercise, I would like to elaborate on his a-religious approach.

\section{Paul Ricoeur}

For Ricoeur (1980:73ff), the issue of revelation represents a formidable question, not only because it may be seen as the first and last question of faith, but also because it has been obscured by so many false debates. Through his development of a hermeneutic of revelation with the category of poetics - on the objective side - and the category of testimony - on the subjective side - he endeavours to unmask these false debates. He furthermore aims to establish an understanding of dependence without heteronomy. Over and against an understanding of the concept of revelation that sets in opposition - on the one hand - an authoritarian and opaque concept of revelation ('revealed truths'), and - on the other hand - reason which claims to be its own master and transparent to itself, he argues that we should carry the notion of revelation back to its most originary level, that is, the discourses of faith, namely, prophetic, narrative, prescriptive, wisdom and hymnic discourse. It is important to take a closer look at the specific character of each one of these originary discourses of faith. For Ricoeur (1980:75), the original nucleus of the traditional idea of revelation can be found in prophetic discourse in which the prophet presents himself as not speaking in his own name, but in the name of another, in the name of Yahweh. Revelation is the speech of another behind the speech of the prophet. Regarding the narrative discourse, he states that the 'events tell themselves', that is, 'history-making events'. In such instances, to speak of revelation is to qualify the events in question as transcendent (act of God) in relation to the ordinary course of history (Ricoeur 1980:77). Prescriptive discourses represent the ethical dimension of revelation. It is constituted by the intention of perfection and holiness. If we speak of revelation as historical, it is not only in the sense that the trace of God may be read in the founding events of the past or in a coming conclusion to history, but in the sense that it orients the history of our practical actions and engenders the dynamics of our institutions (Ricoeur 1980:84-85).

Wisdom literature binds together ethos and cosmos, that is, the sphere of human action and the sphere of the world at the very point of their discordance, namely unjust suffering. Ricoeur (1980:88) goes as far as to state in his beautiful exposition of wisdom as pathos: 'Intimacy with Wisdom is not to be distinguished from intimacy with God'. In reference to hymns of praise, supplication and thanksgiving as the three major genres of hymnic discourse, Ricoeur (1980:88) states that celebration elevates the story and turns it into an invocation. Since the form conveys its very meaning, Ricoeur states emphatically that the notion of revelation may therefore no longer be formulated in a uniform and monotonous fashion, nor may it in its various modalities be included in and dominated by knowledge. This simply means: Ricoeur does not acknowledge that there is something secret about revelation. He even calls it the 'limit-idea' of revelation (Ricoeur 1980:93). For him the idea of revelation is twofold: The God who reveals himself is a hidden God and hidden things belong to him. Therefore revelation can never constitute a body of truths which an institution may boast of or take pride in possessing.
From such a differentiated concept of revelation, Ricoeur (1980:95ff) can subsequently unfold an understanding of revelation which corresponds with the twofold claim of philosophical discourse of transparent objectivity and subjective autonomy. The former is addressed by the 'space of the manifestation of things' (that is, the world of the text and the new being) whereas the latter is addressed by the 'understanding of themselves that humans gain when they allow themselves to be governed by what is manifested and said' (that is, mediating reflection and testimony). Firstly, the 'space of the manifestation of things' is analysed by Ricoeur under the rubric 'poetics', that is, not as a specific literary genre, but rather the totality of these genres in as much as they exercise a referential function that differs from the descriptive referential function of ordinary language and above all of scientific discourse. The concrete dimensions of the 'space of the manifestation of things' can be captured in three concepts, namely the phenomenon of writing in which the world of the text bursts the world of the author; the work as such which shapes the discourse through the operation of literary genres; and the world of the text, that is, the sort of world intended beyond the text as its reference (Ricoeur 1980:99ff). Ricoeur's original unfolding of his understanding of 'poetics' can best be reflected in his own words:

My deepest conviction is that poetic language alone restores to us that participation-in or belonging-to an order of things which precedes our capacity to oppose ourselves to things taken as objects opposed to a subject. Hence the function of poetic discourse is to bring about this emergence of a depth structure of belonging-to amid the ruins of descriptive discourse.

(Ricoeur 1980:101)

For Ricoeur (1980:102), the poetic dimension of language is to be understood as the conjunction of fiction and redescription, of mythos and mimesis, and to which - in recapitalisation of the text (its autonomy), the work (its externality) and the world of the text (its transcendence) - the poetic function adds a split reference. It is this split reference which he calls revelatory since the poetic function incarnates a concept of truth that no longer means verification, but manifestation (that is: "letting what shows itself be'). What 'shows itself' is in each instance a proposed world, a world I may inhabit and wherein I can project my own most possibilities. It is in this sense of manifestation that language in its poetic function is a vehicle of revelation. This a-religious sense of revelation, according to Ricoeur, helps us to restore the concept of biblical revelation (that is, the new being it unfolds before us) to its full dignity. Secondly, in order to oppose and dismantle the pretension of consciousness which is for Ricoeur the most formidable obstacle to the idea of revelation - to constitute itself, he turns to testimony as the category which for him best signifies the self-implication of the subject in this discourse. The self-implication of the subject entails three structural dimensions, namely mediated reflection, a consciousness of belonging-to, and appropriation as selfunderstanding. In acknowledging that there is no immediate self-consciousness, Ricoeur defines mediated reflection as the appropriation of our efforts to exist and of our desire to be through the works which bear witness to that effort and desire. Testimony is therefore included in the structure of reflection. The consciousness of belonging-to reveals our historical situatedness whereas appropriation refers to the self-understanding which is constituted by the issue of the text. The understanding of the self before the text is not to be understood as imposing one's own finite capacity of understanding on it, but as exposing oneself to receive from it a larger self which would be the proposed way of existing that most appropriately responds to the proposed world of the text. For Ricoeur this marks the final defeat of the pretension of consciousness to set itself up as the standard of meaning. Thus: From his convictions that all reflection is mediated and that it (as second order reflection) is bound to the consciousness of belonging-to, and of appropriation as self-understanding before the text, Ricoeur (1980:108-109) argues that this brings about consciousness's abandoning of its pretension to constitute every signification in and beginning 
from itself. It is testimony that introduces the dimension of historical contingency. Testimony as originary affirmation is the 'act that accomplishes the negation of those limitations which affect an individual's destiny'. It is the 'letting go ... of self' (Ricoeur 1980:110). Three dialectical moments subsequently come into play within 'testimony', namely that of event and meaning (that is, to understand ourselves is to continue to attest and to testify to founding events); secondly the trial of false testimony (that is, a sorting and sifting process -- a critical act - in which we, through trial and error, discern and recognise the false and true witness) and finally, testimony about what is seen and a testimony of life (that is when the witness becomes a martyr for truth and the moment in which consciousness renounces its sovereignty). These moments - that is, of originary affirmation in its relation to historical presentation - bring about the renouncing of the sovereign consciousness. How? Not of itself (that is, not through reflection), but by confessing its total dependence on the historical manifestation of the divine. Ricoeur therefore qualifies the renouncing of a sovereign consciousness by stating that:

The experience of testimony can only provide the horizon for a specifically religious and biblical experience of revelation, without ever being able to derive that experience from the purely philosophical categories of truth as manifestation and reflection as testimony..

(Ricoeur 1980:117)

To conclude: How does this understanding of revelation bring about dependence without heteronomy? Ricoeur concludingly states:

Why ... is it so difficult for us to conceive of a dependence without heteronomy? Is it not because we too often and too quickly think of a will that submits and not enough of an imagination that opens itself? ... For what are the poems of the Exodus and the poem of the resurrection ... addressed to if not to our imagination rather than our obedience? And what is the historical testimony that our reflection would like to internalize addressed to if not to our imagination? If to understand oneself is to understand oneself in front of the text, must we not say that the reader's understanding is suspended, derealized, made potential just as the world itself is metamorphosized by the poem? If this is true, we must say that the imagination is that part of ourselves that respond to the text as Poem, and that alone can encounter revelation no longer as an unacceptable pretension, but as non-violent appeal.

(Ricoeur 1980:117)

It is Ricoeur's very special emphasis and understanding of imagination within an a-religious unfolding of revelation which presents in my opinion an exciting conversation partner within the science-theology debate if it is to be broadened from an evolutionary perspective. Especially the manner in which he convincingly argues from a notion of revelation which is to be understood from its most originary discourses of faith. However, before turning to Van Huyssteen's postfoundationalist approach it is inevitably necessary - given the scope of this paper - to turn to another development which spontaneously (and creatively) plays into any unfolding of understanding of revelation, and that is: natural theology.

\section{Revelation and natural theology}

Within theological circles, another debate developed and has become increasingly important, especially on account of the growing interest in promoting dialogue between Christian theology and the natural sciences. That is: natural theology, the reason being that the doctrine of creation is of crucial importance. A few remarks on Thomas Aquinas, John Calvin and the Reformed tradition (McGrath 2001:208ff) in this regard will have to suffice.

In his Summa contra Gentiles, Thomas argues that a fundamental 'likeness to God' exists within the created order as a consequence of God being the cause, in some sense of the word, of all created things. In that no created thing can be said to come into existence spontaneously, the existence of all things can be considered to be a consequence of a relationship of causal dependence between the creation and its creator. This implies that there is a presence in the effect of characteristics that could serve to identify its cause. There are, so to speak, physical or metaphysical fingerprints within what is caused, which provide the basis for an inductive argument to the existence of that cause, and allow at least some aspects of its nature to be established. If God made the world, God's signature may be found within the created order (McGrath 2001:208-209).

In his Institutes, Calvin argues that a general knowledge of God may be discerned throughout creation, namely in humanity, in the natural order and in the historical process itself. Such knowledge is based on two grounds, namely a 'sense of divinity', and the experience of and reflection upon the order of the world. The former posits that God has endowed human beings with some inbuilt sense or presentiment of the divine. It is as if something about God has been engraved in the heart of every human being. The 'engraving' about God implies the universality of religion, a troubled conscience and a servile fear of God. The latter posits that the fact of God as creator, together with an appreciation of the divine wisdom and justice, may be gained from an inspection of the created order, culminating in humanity itself. The created order, as a theatre or mirror for displaying the divine presence, nature and attributes, is open for all 'reflective' eyes to see, and to arrive at the idea of God. Although God is invisible and incomprehensible, God wills to be known under the form of created and visible things, by donning the garment of creation (cf. McGrath 2001:210).

In both the Gallic Confession of Faith (1559) and the Belgic Confession (1561) it is argued that knowledge of God comes by two means, namely in God's works and more clearly in God's Word. The Belgic Confession talks about creation, preservation and government of the universe which is before our eyes as a most beautiful book, in which all creatures, great and small, are like so many characters that lead us to contemplate the invisible things of God. All of these, according to the Confession, are sufficient to convince humanity, and leave it without excuse. However, God is known more clearly and fully in his Word (cf. McGrath 2001:212). The so-called two books tradition, which developed within Reformed theology and which regarded nature and Scripture as two complementary sources of our knowledge of God has been influential in wider reflective circles. To name but a few wider reflective circles: In the 17th century, Francis Bacon talks about 'the book of God's Word' and the 'book of God's works'. Not much later Robert Boyle remarked that as the two great books of nature and of Scripture have the same author, so the study of the latter does not at all hinder an inquisitive man's delight in the study of the former. He also calls the former 'God's epistle written to mankind'. So too Sir Thomas Browne who states that there are two books from whence he collects his divinity, namely God's written Word and - as he calls it - another of his servant, nature. For Browne, the latter is a universal and public manuscript that lies expansed unto the eyes of all, so that those who never saw him in the one have discovered him in the other (cf. McGrath 2001:212).

Against this background of Ricoeur's a-religious understanding of revelation and the 'two books' tradition stemming from the natural theology debate, I would like to turn to the postfoundationalist approach of Van Huyssteen, pursuing the question of an interdisciplinary re-visioning of the concept of revelation.

\section{WHAT HAVE OUR GENES TO DO WITH BELIEF? (AND NO LONGER: WHAT HAS ATHENS TO DO WITH JERUSALEM?)}

\section{Introduction}

Contemporary cosmology explicitly argues for treating the observable universe as a single object. Theological reflection should not only take this demand seriously, but must make work of it methodologically by accepting the challenge to engage wholeheartedly within the interdisciplinary conversation 
on life processes and the meaning of life if it is to lay claim to credibility. At the contemporary feast of this argumentative discourse, we find as newly self-appointed rational-masterof-interdisciplinary-ceremonies, evolutionary epistemology. Self-appointed, since we cannot be content with a plurality of different, fragmented and unrelated forms of knowledge. I wish to turn - following my introductory reference to Knight's suggestion that it should be explored - to one of the influential 'diners', namely the postfoundationalist approach of Wentzel van Huyssteen.

\section{Wentzel van Huyssteen}

In his Alone in the World?, Van Huyssteen's (2006) evolved understanding of rationality over a period of more than three decades, brought him to the ultimate evolutionary origins of human rationality itself. This is the subsequent concrete unfolding of his argument in his preceding Duet or Duel (1998) in which he states:

Evolutionary epistemology ... reveals the biological roots of all human rationality and should therefore lead precisely to an interdisciplinary account of our epistemic activities. The basic assumption of evolutionary epistemology is that we humans, like all other beings, result from evolutionary processes and that consequently, our mental capacities are constrained and shaped by the mechanism of biological evolution.

(Van Huyssteen 1998: xiii-iv)

This interdisciplinary account ${ }^{1}$ finds concrete expression in two related endeavours, both culminating in two specific epistemological liberations, namely (a) his attempt at developing a comprehensive epistemology that is rooted in the biological origins of human rationality as understood by evolutionary epistemologists, and (b) his exploration of human uniqueness from both theological and scientific perspectives. The first endeavour opens up the conviction that all knowledge is biologically rooted, and that all knowledge is grounded in human evolution. He thus argues that the common biological origin of all forms of knowledge reveals a universal intent that links together all our diverse and complex epistemic activities. This endeavour culminates in the liberation from epistemic narcissism. In the second related endeavour, Van Huyssteen grapples with the challenge posed by the process of human evolution for our understanding of human uniqueness. This endeavour culminates in the liberation from epistemological tribulism. This found expression in his Gifford Lectures at the University of Edinburgh, Scotland (2004), published in 2006 as Alone in the World?

Taking as vantage point his now substantiated and established conviction that the domain of religious faith and the domain of scientific thought share in the resources of human rationality and are therefore able to be linked in interdisciplinary dialogue (Van Huyssteen 2006:1-43), he links the question of human uniqueness to evolutionary epistemology (with a special focus on the prehistory of the human mind). It unfolds as a multidimensional interdisciplinary discourse in which perspectives from theology, epistemology and the sciences meet along diversely intersecting lines (Van Huyssteen 2006:45-109).

He argues conclusively that evolutionary epistemology clearly shows that the human propensity for metaphysical and religious belief should be seen as the result of specific interactions between early humans and their lifeworlds. Subsequently he shifts the focus to one of the core traditions of the Christian faith, namely (2006:13) makes the important remark that crucial to Van Huyssteen's argument against a Dawkins-like reductionism of religious awareness evolution, the latter being based on the former but not reducible to it. This remark should be kept in mind regarding Van Huyssteen's understanding of the ultimate evolutionary origins of human rationality.

2.Reynhout (2006:14-15) rightly remarks: Alone in the world? is impressive, not only for its comprehensive treatment of various scientific and theological perspectives on human uniqueness, but also for the way in which van Huyssteen attempts to stay true to his own postfoundationalist, interdisciplinary methodology. the doctrine of the imago Dei (Van Huyssteen 2006: 111-162), arguing that the porousness of the boundaries between theology and the sciences allows for a creative (two-pronged) rethinking of this notion in Christian theology. According to Van Huyssteen, on the one hand, the relative convergence of theological and scientific arguments on the issue of human uniqueness gives us, according to him, an argument for the plausibility and comprehensive nature of religious and theological explanations for a phenomenon as complex as Homo Sapiens (Van Huyssteen 2006:113ff).

On the other hand, he argues simultaneously that scientific notions of human uniqueness help us to ground theological notions of human distinctiveness in the reality of flesh-and-blood, real-life, embodied experiences, and thus protect theological reflection from overly complex abstractions when trying to revision the notion of the imago Dei. Taking his own argument now concretely seriously, Van Huyssteen subsequently turns his revision to a neglected voice on this crucial issue, namely contemporary paleoanthropology ${ }^{3}$ (Van Huyssteen 2006:163215), showing that the prehistory of the human mind (including the evolution of consciousness and self-awareness) reveals the remarkable cognitive fluidity (a concept that he has taken over from Steven Mithen) ${ }^{4}$ of our mental abilities. With three distinct disciplinary lines (evolutionary biology, theology and paleoanthropology 5 ) of argument on human uniqueness now transversally intersecting, Van Huyssteen (2006:217ff) not only evaluates the intersecting of the three lines, but 'thickens the (intersecting) plot'by introducingnew interdisciplinary proposals (drawing on linguistics, neuroscience and neuropsychology).

${ }^{6}$ From thisevaluation, heargues that(a) thecapacity for spirituality can be understood as an emergent consequence of the symbolic transformation of cognition and emotions, thus explaining why the propensity for religion and religious experience can be regarded as an essentially universal human attribute (Van Huyssteen 2006:233ff); that (b) a postfoundationalist approach to human uniqueness as an interdisciplinary problem should alert us to the fact that religious imagination cannot be discussed abstractly or treated as a generic given, but can be discussed and evaluated only within the concrete context of specific religions and concrete theologies (Van Huyssteen 2006: 261ff); and that (c) theologians should revisit the way notions of the imago Dei are constructed since interpretations thereof have indeed varied dramatically throughout the long history of Christianity (Van Huyssteen 2006: 267-70; 271ff).

In his interdisciplinary proposal on human uniqueness, Van Huyssteen argues that theologians must rethink personhood in terms of imagination, symbolic propensities, and cognitive fluidity that acknowledges humanity's close ties with the animal world. He develops theories of the imago Dei that recognise that this quality has emerged by natural evolutionary processes and suggests that we reconceive of the imago Dei in a highly contextualised, embodied sense ( $c f$. Van Huyssteen 2006:276ff). Staying true to his postfoundationalist, interdisciplinary methodological position, and freed from epistemic narcissism and epistemological tribulism, Van Huyssteen thus ultimately substantiates his 'transversal exercise' that theology can engage in rational discourse across interdisciplinary lines.

3.According to Van Huyssteen (2006:168ff), the materiality of these prehistoric images (e.g. hand prints, bird man, and wounded men) that are to be found in the Palaeolithic cave art in south-western France and the Basque Country in northern Spain might not tell us much about our remote human or hominid origins, but the images certainly reveal much of what it means to be human, and as such, dramatically reveal the complexity of the cognitively fluid human mind.

4.Cognitive fluidity is evidenced by the human capacity for imagination, creativity, and symbolic thought, which in turn are prerequisites for the emergence of science, art and religion (cf. Reynhout 2006:13).

5.The three distinctive disciplinary lines are namely, the epistemological argument from evolutionary biology, the historically diverse and rather fragmented argument from theology, and the complex, multileveled scientific argument from contemporary paleoanthropology.

6. The focus of his evaluation of the (intersecting) 'plot' is on the question on how symbolic representation, as the principal cognitive signature of humans, is grounded in our remarkable mimetic and linguistic abilities (cf. Van Huyssteen 2006:233ff). 
Thus: Given the argumentative link for the evolutionary connectedness of our genes with belief, my question is: What does this imply for re-imagining the concept of revelation?

\section{TENTATIVE FRAMEWORK FOR THE RE-IMAGINING OF AN INTERDISCIPLINARY CONCEPT OF REVELATION}

In the light of the above-mentioned exposition, I would tentatively like to propose the following theses:

- $\quad$ From the brief overview of models of revelation, Ricoeur's specific understanding of an a-religious concept of revelation as welcoming address, and within the context of an understanding of creation (nature) as God's 'epistle to humanity', it is clear that a concept of revelation is acknowledged as being constitutive for theological reflection. If in its most simplified definition it means 'to uncover / to make known something which was previously unknown', and in the context of Christian theology, 'God's self-revelation', then surely it implies some kind or form of knowledge claims.

- If such theological knowledge claims regarding revelation wishes to maintain its identity without retreating to an esoteric world of private, insular knowledge claims, it should consciously seat itself at the interdisciplinary table of reflection on the genesis of knowledge.

- At the interdisciplinary table of reflection on the genesis of knowledge, theological reflection will find a justification for its reservation at the table, as well as pointers for making knowledge claims.

- $\quad$ The former, namely a justification for its reservation at the table, is announced by evolutionary epistemology. The latter, namely the pointers, are to be formulated in the interdisciplinary space that creatively opens up in the dialogue with evolutionary epistemology.

- Regarding the justification for its reservation at the table, evolutionary epistemology as a theory of cognition reveals the biological roots of all human rationality, and thus the shared resources of human rationality for both scientific and theological reflection (Van Huyssteen). It subsequently opens space for an interdisciplinary account of our epistemic activities and facilitates a postfoundationalist notion of rationality, that is, it takes us beyond traditional disciplinary boundaries.

- Regarding the formulation of pointers, theological reflection is made aware not only of being shaped by its cultural, social and historical contexts, but also by the biological roots of human rationality (Van Huyssteen). However, theological reflection as cultural achievement, so intimately entwined with the process of biological evolution, is ultimately not determined by it. It is indeed as Keith Ward once put it, designed to lead to levels of explanation and reality beyond itself.

- If our genes do not completely determine our culture and our rational abilities, then it may be reasonable to expect that our genes, our culture, and our rational abilities may also not completely determine the enduring and persuasive need for metaphysics, and ultimately for life-transforming religious faith. This awareness enables theological reflection to move beyond so-called narrow options of either/or, that is, for example of naturalism and supernaturalism.

- This movement beyond so-called narrow options is prompted by the shared focal interest (of scientific and theological reflection) in life processes, but is also interested in more since it is concerned with the interpretation of existence. In 'more', since nature is not designed to answer all the metaphysical questions.

- Regarding the 'more', that is, the interpretation of existence, evolutionary epistemology tells us that some kind of metaphysics seems to be a general characteristic of all humans, and thus of the naturalness of religion, and of belief.

- In religious belief we find a drive (the element of hope?) toward something transcending human powers as reflected in the fabric of the universe, a reality greater than, and transcending empirical reality. This drive over centuries finds a natural witness in the phylogenetic memory of humanity.

- $\quad$ The phylogenetic memory of humanity represents - in my opinion - one of the exciting lines for opening up a new way for crossing boundaries between disciplines in re-imagining the concept of revelation from a postfoundationalist perspective. The theological line which I consider to be fruitful to pursue for the interdisciplinary conversation is Ricoeur's focus on the poetic dimension of language (that is, the conjunction of mythos and mimesis), and the category of testimony which addresses our imagination. No longer can traditional understandings of revelation in which revelation is mostly unfolded in a uniform and monotonous fashion be upheld with integrity. No longer can understandings of revelation be justified which originate from a very limited scope of revelation simply understood as knowledge coming from a supranatural source that breaks into the natural world.

- The historical-poetical 'Testament' (that is, Scripture and nature) can subsequently be re-imagined as an emerging 'one book' (albeit differentiated with regard to 'information') in the ongoing process of evolution in which our ability for rational knowledge and humanity's endless quest for ultimate meaning finds an existential village ${ }^{7}$.

- Being 'told' what God is like can thus unfold in very different (dazzling) manners within life experiences and testimonies thereto, life processes, nature and its mindboggling evolutionary history in all its diversity and fascinating readings ${ }^{8}$. Such a re-imagining of revelation is in my opinion not only to be understood as celebrating the mystery of the "revealed God", but also as an acknowledgment in a credible manner of the depth, width and height of that very mystery that sustains humanity as imago Dei.

\section{NOTE}

Paper presented on the 3 May 2008 at the 12th ESSSAT Congress, Sigtuna, Sweden and submitted to HTS for publication. On invitation, this same paper was reworked and read in Aug. 2008 at the annual congress of the South African Science and Religion Forum, and subsequently published in 2009 by the Research Institute for Theology and Religion with the title: 'What have our genes to do with religion?' in C.W. Du Toit (ed.), 'The evolutionary roots of religion: cultivate, mutate or eliminate', SASRF 13, 189-211. 


\section{REFERENCES}

Dulles, A., 1983, Models of revelation, Gill \& Macmillan, Dublin.

Du Toit, C.W. (ed.), 2000, Evolution and creativity, Research Institute for Theology and Religion, Pretoria.

Gregersen, N.H., 2000, 'God: the creator of creativity', in C.W. Du Toit (ed.), Evolution and creativity, pp. 25-56, Research Institute for Theology and Religion, Pretoria.

Gregersen, N.H., 2006, 'What theology might learn (and notlearn) from evolutionary epistemology: A postfoundationalist theologian in conversation with Pascal Boyer', in L.F. Shults (ed.), The evolution of rationality: interdisciplinary essays in honor of J Wentzel van Huyssteen, pp. 306-326, Eerdmans Grand, Rapids.

Jüngel, E., 1967, Gottes Sein ist im Werden, Tübingen, Mohr.

Knight, C.C., 2003., 'sv. Revelation', Encyclopedia of science and religion, MacMillan, New York, vol. 2 (J-Z).

McGrath, A.E., 2001, Christian theology: An introduction, 3rd edn., Blackwell, Oxford.

Pannenberg, W., 1977, Faith and reality, Search Press, London.

Reynhout, K.A., 2006, 'The evolution of Van Huyssteen's model of rationality', in L.F. Shults (ed.), The evolution of rationality: interdisciplinary essays in honor of J Wentzel van Huyssteen, pp. 1-16, Eerdmans, Grand Rapids.

Ricoeur, P., 1980, Essays on Biblical interpretation, Fortress Press, Philadelphia.
Shults, L.F. (ed.), 2006, The evolution of rationality: Interdisciplinary essays in honor of J. Wentzel van Huyssteen, Eerdmans, Grand Rapids.

Stone, J.A., 2006, 'Van Huyssteen in context: a comparison with Philip Hefner and Karl Peters', in L.F. Shults (ed.), The evolution of rationality: Interdisciplinary essays in honor of $J$. Wentzel van Huyssteen, pp. 73-86, Eerdmans, Grand Rapids.

Van Huyssteen, W., 1997, Essays in postfoundationalism, Eerdmans, Grand Rapids.

Van Huyssteen, W., 1998, Duet or duel?, Trinity Press International, Harrisburg.

Van Huyssteen, W., 1999a, 'Evolution and the human mind: How special are we really?', in C.W. Du Toit (ed.), Evolution and creativity, pp. 130-180, Research Institute for Theology and Religion, Pretoria.

Van Huyssteen, W., 1999b, 'Faith and knowledge: Our common evolutionary heritage?', in C.W. Du Toit (ed.), Evolution and creativity, pp. 181-216, Research Institute for Theology and Religion, Pretoria.

Van Huyssteen, W., 1999c, The shaping of rationality: Toward interdisciplinarity in theology and science, Eerdmans, Grand Rapids.

Van Huyssteen, W., 2006, Alone in the world?, Eerdmans, Grand Rapids.

Van Huyssteen, W., 2007, A brief overview of a theologian's journey to interdisciplinarity, Unpublished document. 